\title{
The Separation of Gaseous Mixture with Composite Microporous Glass Membranes at High Temperature
}

\author{
HARUHIKO OHYA, SUSUMU SATO, AKIRA ISHII, \\ YOUICHI NEGISHI, KANJI MATSUMOTO
}

\begin{abstract}
Department of Material Science and Chemical Engineering, Faculty of Engineering, Yokohama National University, 156 Tokiwadai Hodogaya-ku Yokohama, 240 (Japan)
\end{abstract}

Separation of gaseous mixture was carried out up to $773 \mathrm{k}$ using composite microporous glass membranes coated on the surface of a porous ceramic tubings. The composition of the metal alkoxide solution used in the coating process was $\mathrm{Si}\left(\mathrm{OC}_{2} \mathrm{H}_{5}\right)_{4}: 27.9, \mathrm{C}_{2} \mathrm{H}_{5} \mathrm{OH}: 42.0, \mathrm{H}_{2} \mathrm{O}: 26.2, \mathrm{HCl}: 0.3$ and $\mathrm{H}_{3} \mathrm{BO}_{3}: 3.6$, in weight \%.

With ceramic tubings supplied from TOTO Co., Ltd., much thinner microporous glass membranes can be made because 5 times of coating was enough to get without cracks, comparing at least 7 times for TDK Co., Ltd.. The membrane can permeate only $\mathrm{H}_{2} \mathrm{O}$ from thermochemical reaction gas mixture of $\mathrm{H}_{2}$ and $\mathrm{H}_{2} \mathrm{O}$ at the flux rate of $37 \mathrm{~kg} /\left(\mathrm{m}^{2} \cdot\right.$ day) at trans-membrane pressure $0.196 \mathrm{MPa}$ and at $773 \mathrm{~K}$.

Key words : Membrane, Composite membrane, Gas separation, Ceramic tubing, Metal alkoxide coating, Inorganic membrame.

\section{Introduction}

The conversion of water into hydrogen by thermochemical water decomposition process is couple of percent ${ }^{1)}$. If it is possible to separate hydrogen from the reaction gas without phase change, the thermal efficiency of the process may increase and the cost of hydrogen may decrease.

In this study, microporous composite glass membranes which might withstand the very corrosive gas containing $\mathrm{HBr}$ at high temperature up to $500^{\circ} \mathrm{C}$, was prepared for the purpose to study the possibility of separation of hydrogen from the reaction gas of thermochemical water decomposition process.

Few reports were devoted to gas separation with the inorganic membranes, such as hydrogen separable membranes development in $\mathrm{C}_{1}$ Chemistry project sponsored by MITI ${ }^{2,3)}$., separation of hydrogen from hydrogen and hydrogen sulfide mixture with microprous glass membranes ${ }^{4,5)}$ and
Table 1 Dimensions of Porous Ceramic Tubings

\begin{tabular}{l|c|c}
\hline \multicolumn{1}{c|}{ Supplior } & $\begin{array}{c}\text { TDK } \\
\text { Co., Ltd. }\end{array}$ & $\begin{array}{c}\text { TOTO } \\
\text { Co., Ltd. }\end{array}$ \\
\hline Pore Size $[\mathrm{nm}]$ & 500 & 500 \\
Outer Diameter $[\mathrm{mm}]$ & 5.0 & 5.5 \\
Inner Diameter $[\mathrm{mm}]$ & 2.0 & 3.9 \\
Porosity [\%] & c. a. 45 & c. a. 45 \\
\hline
\end{tabular}

inorganic membrane reactors such as dehydrogenation of cyclohexane ${ }^{6)}$.

The so-called Knudsen gas diffusion occurred in microporous membranes is applied to separate gaseous mixtures composed of different molecular weight components. In the case mentioned above, the lightest molecule $\mathrm{H}_{2}$ permeates selectively through the inorganic membrane.

Silica-alumina gel membranes can effectively separate condensable gases such as water vapor from gaseous mixtures of condensable gas and non-condensable, possibly by the mechanism of 


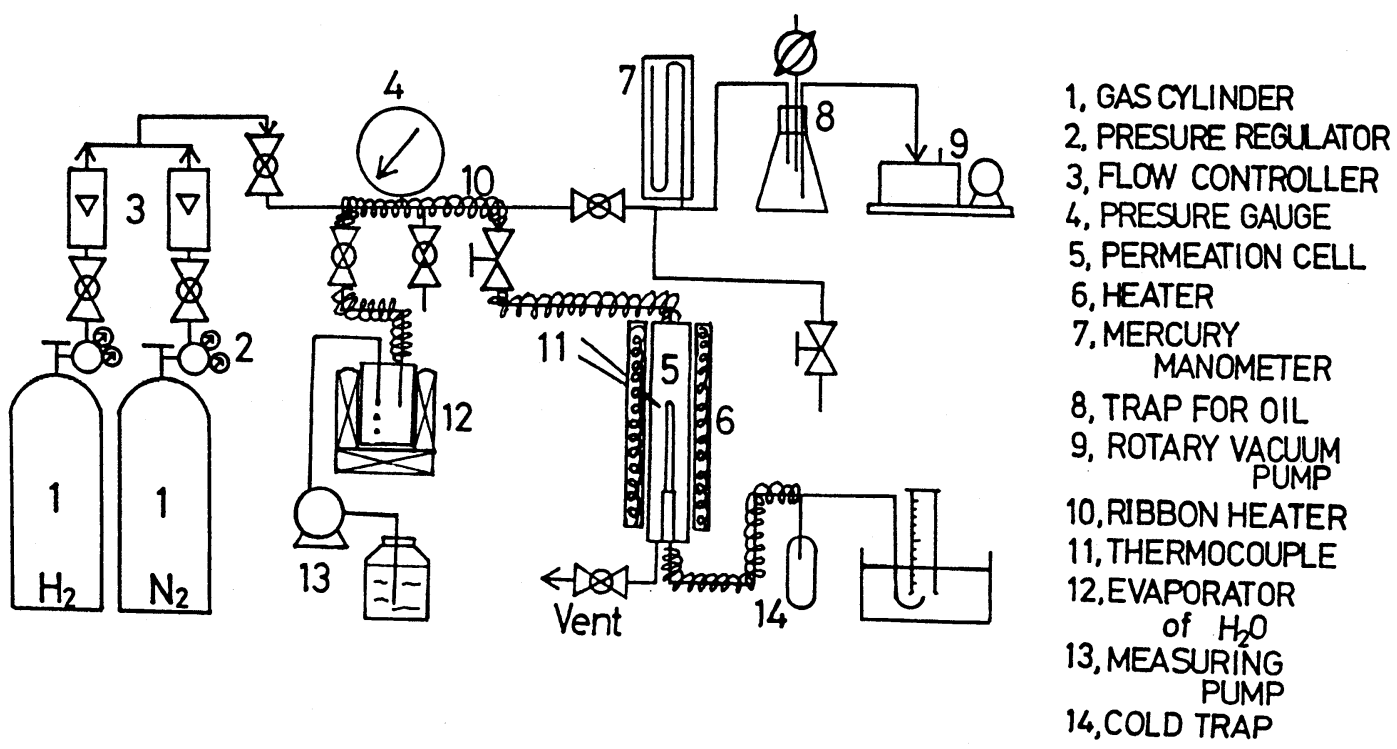

Fig. 1. Schematic diagram of the experimental apparatus.

capillary condensation ${ }^{729}$. Lee and Hwang ${ }^{10)}$ studied the condensable vapor through microporous media experimentally as well as theoretically. In this paper, at high temperature, are studied the separation of gaseous mixture of hydrogen and water vapor, and nitrogen and water vapor with composite microporous glass membranes on ceramic tubing prepared by the method described in the previous paper.

\section{Experimental}

\section{Membrane}

A thin layer of microporous glass was deposited on the surface of two types of porous ceramic tubings of which dimensions are listed in Table 1 , using the method described in the previous paper ${ }^{11)}$. The composition of the metal alkoxide solution used in the coating process is $\mathrm{Si}\left(\mathrm{OC}_{2} \mathrm{H}_{5}\right)_{4}$ : $27.9, \mathrm{C}_{2} \mathrm{H}_{5} \mathrm{OH}: 42.0, \mathrm{H}_{2} \mathrm{O}: 26.2, \mathrm{HCl}: 0.3$ and $\mathrm{H}_{3}$ $\mathrm{BO}_{3}: 3.6$ in weight $\%$.

\section{Apparatus And Procedures}

A schematic diagram of the apparatus used for the measurement of gas permeabilities and for gas separation experiments is shown in Fig. 1.
Before introducing the gas into the system, the system was either evacuated for one night or displaced by nitrogen. The feed gas $\left(\mathrm{H}_{2}, \mathrm{~N}_{2}\right.$, $\mathrm{CO}_{2}$, and water vapor; a mixture of $\mathrm{H}_{2}$ and water vapor, $\mathrm{H}_{2}: \mathrm{H}_{2} \mathrm{O}=1: 1, \mathrm{~N}_{2}$ and water vapor, $\mathrm{N}_{2}$ : $\mathrm{H}_{2} \mathrm{O}=1: 1$ ) was introduced at the high-pressure side. The pressure of feed gas was kept in the range of $49 \sim 196 \mathrm{kPa}$ by a pressure-control valve. The temperature of feed gas was kept in the range of $673 \sim 773 \mathrm{~K}$ by a thermoregulater.

The composition of feed gas and permeate after $\mathrm{H}_{2} \mathrm{O}$ trapped was determined with a thermal conductivity gas chromatograph (Hitachi GC-164T) using a Gaskuropack 54 column (Gaskuro Kogyo ). When the permeation rates measured after $\mathrm{H}_{2} \mathrm{O}$ trapped remained constant, they were measured using the water displacement method, while the $\mathrm{pH}$ of the water was kept $<3$ by adding $\mathrm{HCl}$.

\section{Results and Discussions}

\section{Pure gas permeability}

Figure 2 shows the relationship between the pure gas permeation fluxes of $\mathrm{H}_{2}, \mathrm{~N}_{2}, \mathrm{CO}_{2}$ and $\mathrm{H}_{2} \mathrm{O}$ through microporous glass membranes with 10 and 15 coatings on TDK ceramic tubing at $673 \mathrm{~K}$ 

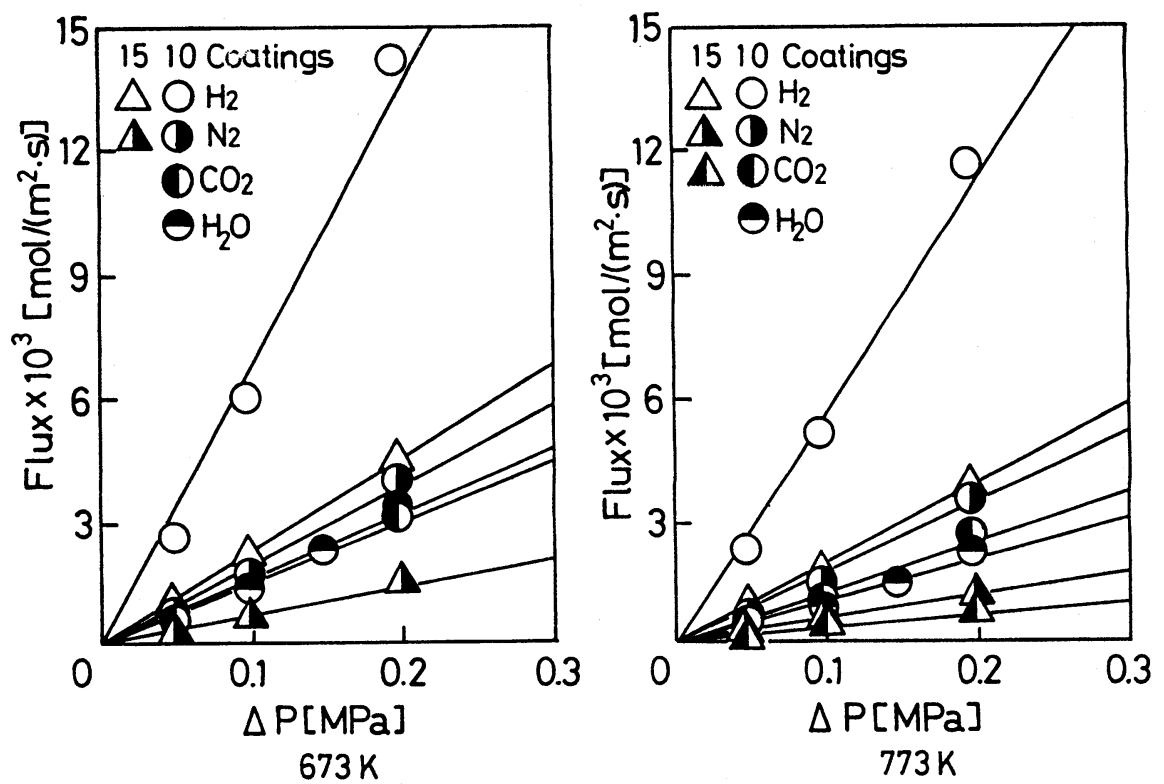

Fig. 2. The relationship between the pure gas permeation fluxes of $\mathrm{H}_{2}$, $\mathrm{N}_{2}, \quad \mathrm{CO}_{2}$ and $\mathrm{H}_{2} \mathrm{O}$ through the microporous glass membranes with 10 and 15 coatings on TDK ceramic tubings and transmembrane pressure at $673 \mathrm{~K}$ and $773 \mathrm{~K}$.

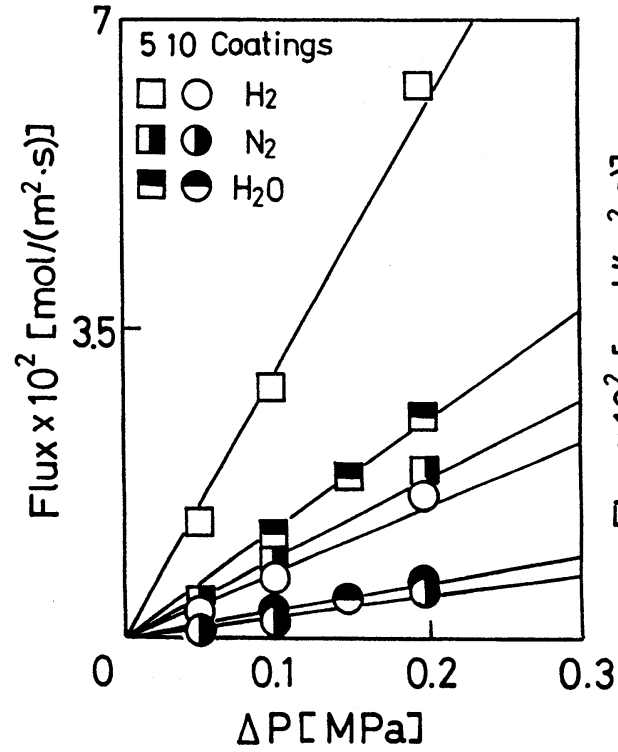

$673 \mathrm{~K}$

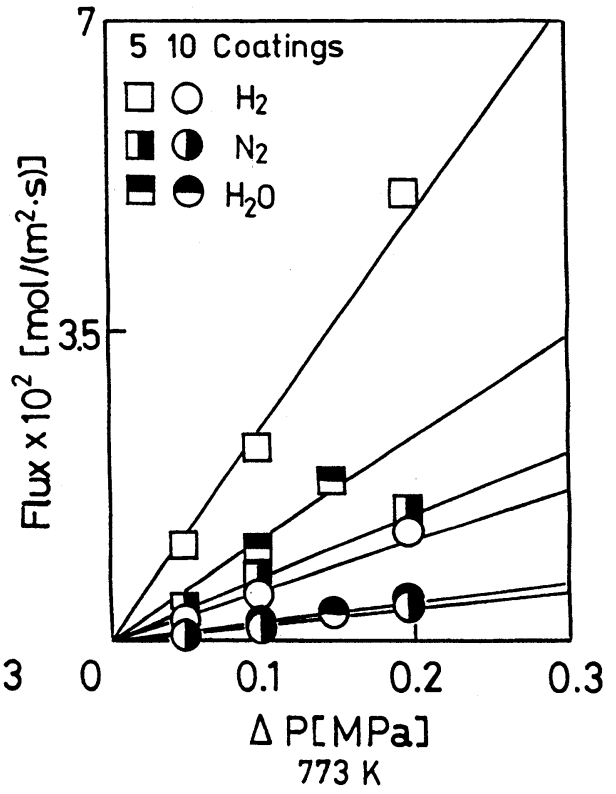

$773 \mathrm{~K}$

Fig. 3. The relationship between the pure gas permeation fluxes of $\mathrm{H}_{2}, \mathrm{~N}_{2}$ and $\mathrm{H}_{2} \mathrm{O}$ through the microporous glass membranes with 5 and 10 coatings on TOTO ceramic tubings and trans-membrane pressure at $673 \mathrm{~K}$ and $773 \mathrm{~K}$. 


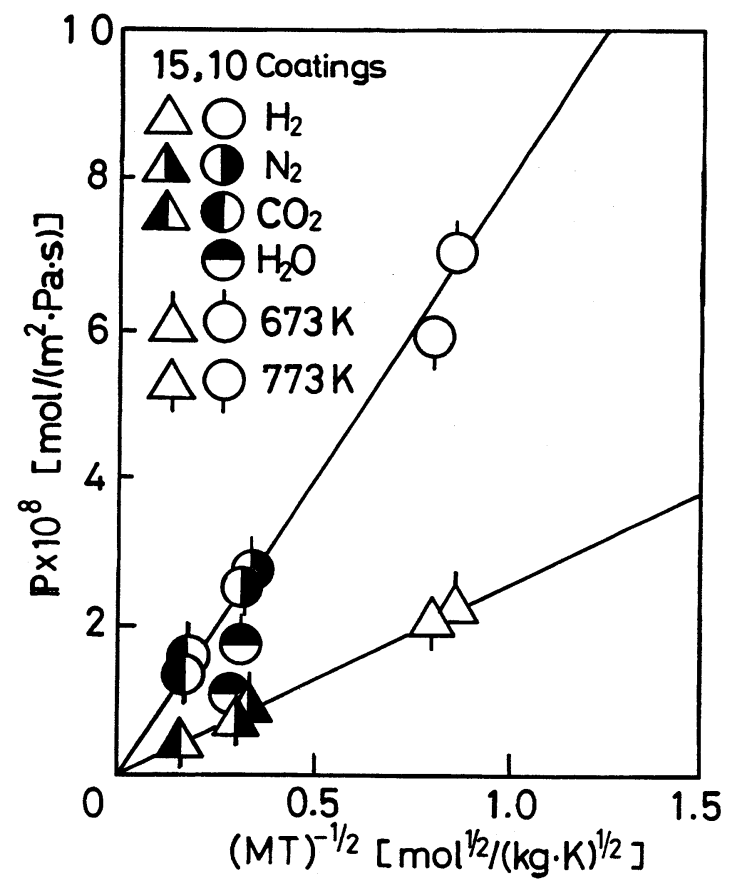

Fig. 4. The relationship between permeabilities of $\mathrm{H}_{2}, \mathrm{~N}_{2}, \mathrm{CO}_{2}$ and $\mathrm{H}_{2} \mathrm{O}$ and reciprocal of the square root of the product of the molecular weight and absolute temperature on TDK ceramic tubings.

and $773 \mathrm{~K}$. Fluxes with 10 coatings are about 3 times larger than with 15 coatings.

Figure 3 shows the relationship between the pure gas permeation fluxes of $\mathrm{H}_{2}, \mathrm{~N}_{2}$ and $\mathrm{H}_{2} \mathrm{O}$ through microporous glass membranes with 5 and 10 coatings on TOTO ceramic tubing at the same temperatures. Fluxes with 5 coating are about 4 times larger than with 10 coatings. The $\mathrm{H}_{2}$ fluxes at $0.196 \mathrm{MPa}$ and at $773 \mathrm{~K}$ through the microporous glass membranes with 10 coatings on TDK and TOTO ceramic tubings are both $1.22 \times 10^{-2} \mathrm{~mol} /$ $\left(\mathrm{m}^{2} \cdot \mathrm{s}\right)$. As mention in the previous paper, at least 7 times coating's was necessary to get microporous glass membranes without cracks on TDK ceramic tubing, but on TOTO ceramic tubing, 5 times coating is enough to get perfect membrane, which shows the $\mathrm{H}_{2}$ flux at $0.196 \mathrm{MPa}$ and at $773 \mathrm{~K}$ is $5.0 \times 10^{-2} \mathrm{~mol} /\left(\mathrm{m}^{2} \cdot \mathrm{s}\right)$ by 4 times more than that with 10 coatings on TDK. Therefore, ceramic tubing supplied from TOTO Co., Ltd. is better than

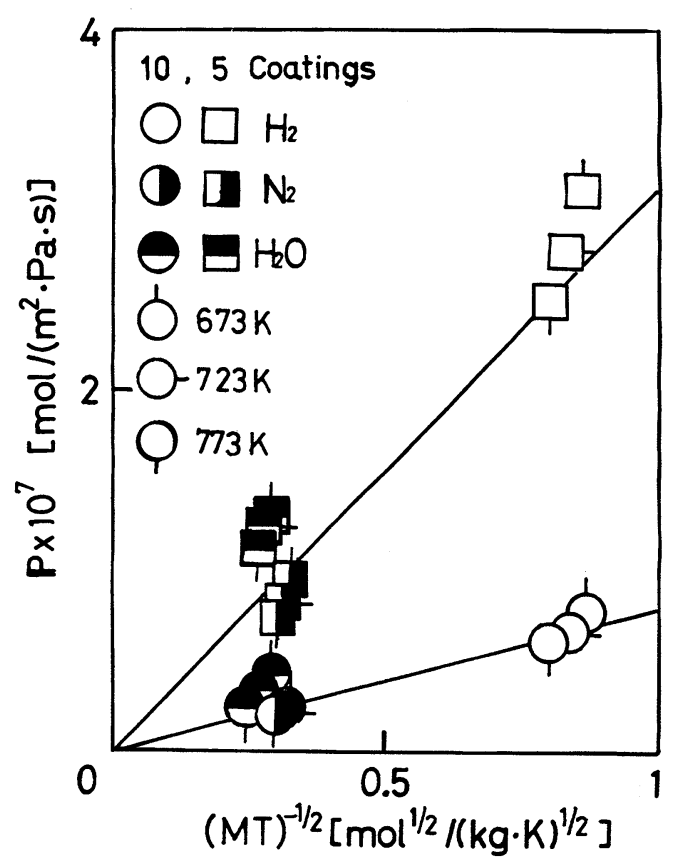

Fig. 5. The relationship between permeabilities of $\mathrm{H}_{2}, \mathrm{~N}_{2}$, and $\mathrm{H}_{2} \mathrm{O}$ and reciprocal of the aquare root of the product of the molecular weight and absolute temperature on TOTO ceramic tubings.

TDK Co., Ltd..

Figure 4 and 5 show the relationship between permeabilities of $\mathrm{H}_{2}, \mathrm{~N}_{2}$ and $\mathrm{H}_{2} \mathrm{O}\left(\mathrm{CO}_{2}\right.$ only in Fig.4) and reciprocal of square root of the product of the molecular weight and absolute temperature. The relationship shows good linearity which means Knudsen flow may be predominant in this permeation mechanism.

\section{Permeability of gaseous mixture}

Figure 6 and 7 show the relationship between permeation fluxe of $50-50 \%$ gaseous mixture of $\mathrm{H}_{2} \mathrm{O}-\mathrm{H}_{2}$ and $\mathrm{H}_{2} \mathrm{O}-\mathrm{N}_{2}$ and transmembrane pressure. The analysis of the permeate showed that $\mathrm{H}_{2}$ and $\mathrm{N}_{2}$ were not found and that all the constituent of the permeate was $\mathrm{H}_{2} \mathrm{O}$. The solid lines shown in Fig. 6 and 7 are drown from the data shown in Fig. 2 and 3 respectively. It is very interesting that the permeation flux of $\mathrm{H}_{2} \mathrm{O}$ through the membrane from $50-50 \%$ gaseous mixture of $\mathrm{H}_{2} \mathrm{O}-\mathrm{H}_{2}$ and 


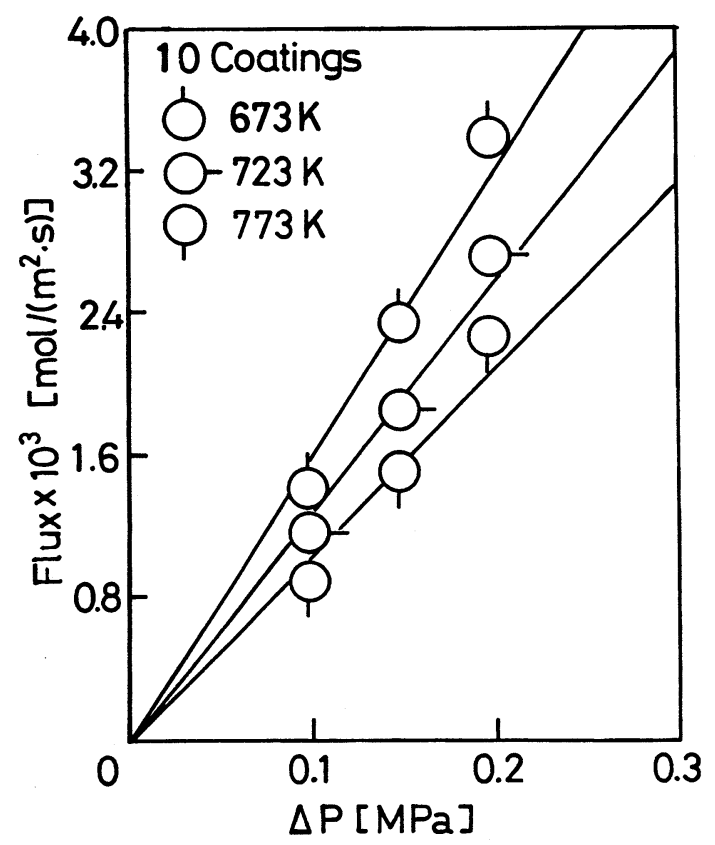

Fig. 6. The relationship between permeation flux of $50-50 \%$ gaseous mixture of $\mathrm{H}_{2} \mathrm{O}-\mathrm{H}_{2}$ and trans-membrane pressure on TDK ceramic tubings.

$\mathrm{H}_{2} \mathrm{O}-\mathrm{N}_{2}$ is same as that measured with pure $\mathrm{H}_{2} \mathrm{O}$ gas at the same trans-membrane pressure of the mixture. These two facts mean that $\mathrm{H}_{2} \mathrm{O}$ vapor may absorb on the sarface of the micropore in the membrane and flow through it under the pressure of the gaseous mixture or pure water vapor as suggestedby Asaeda et al. ${ }^{7 \sim 9)}$. Flux of $\mathrm{H}_{2} \mathrm{O}$ decreases with the increase of temperature and coating time.

\section{Conclusion}

1. Ceramic tubing supplied from TOTO Co., Ltd. was better than TDK Co., Ltd. and was coated at least 5 times to get microporous glass membranes without cracks.

2. Knudsen flow is considered to be predominant in this gas permeation mechanism for pure gases, $\mathrm{H}_{2}, \mathrm{~N}_{2}, \mathrm{H}_{2} \mathrm{O}$ and $\mathrm{CO}_{2}$.

3. When $50 \sim 50 \%$ gaseous mixture of $\mathrm{H}_{2} \mathrm{O}-\mathrm{H}_{2}$ and $\mathrm{H}_{2} \mathrm{O}-\mathrm{N}_{2}$ were pressured through the microporous glass membrane up to $773 \mathrm{~K}$, only water

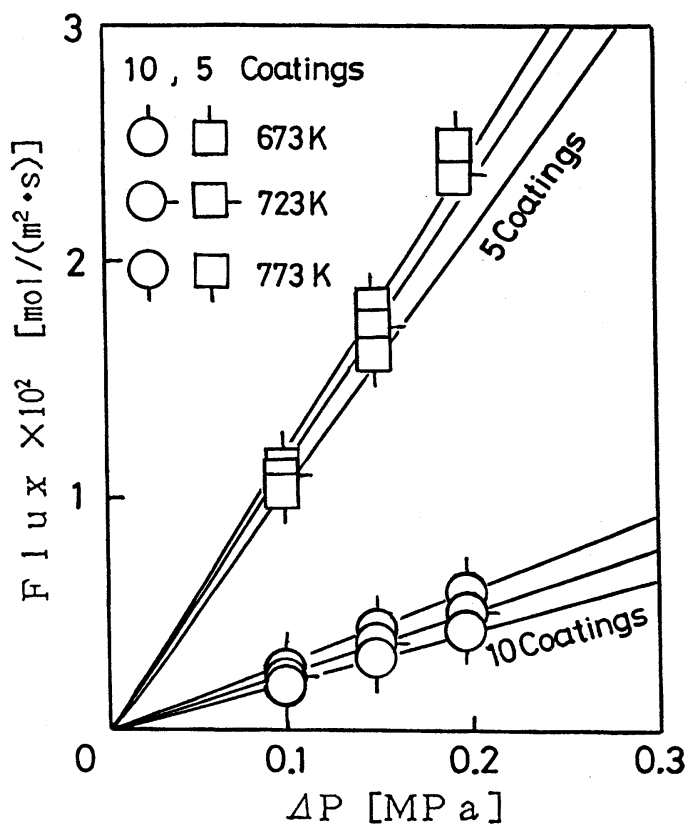

Fig. 7. The relationship between permeation flux of $50-50 \%$ gaseous mixture of $\mathrm{H}_{2} \mathrm{O}-\mathrm{H}_{2}$ and trans-membrane pressure on TOTOceramic tubings.

vapor permeated through the membrane and it was found separation factor was virtually infinite.

4. The microporous glass membrane with 5 coating on TOTO ceramic tubing will do the job to separate $\mathrm{H}_{2} \mathrm{O}$ from thermochemical reaction gas mixture of $\mathrm{H}_{2}$ and $\mathrm{H}_{2} \mathrm{O}$ at the flux rate of $37 \mathrm{~kg} /$ $\left(\mathrm{m}^{2} \cdot\right.$ day $)$ at trans-membrane pressure $0.196 \mathrm{MPa}$ and at $773 \mathrm{~K}$.

\section{Acknowledgment}

This work was supported by a Grant-in-Aid for energy research (No. 62603005, 63603007)from the Ministry of Education, science, and culture of Japan.

\section{Literature Cited}

1) Kameyama, H. and K. Yoshida : “Br-Ca-Fe water decomposition cycles for hydrogen production" Hydrogen Energy System, Proc. of the 2nd World Hydrogen Energy Conf. Oct. 1978 Zuric, Pergamon, Press pp. 829-850

2) Shindo, Y., T.,Hakuta, H. Yoshitome and H. Inoue : J. Chem. Eng. Japan, 16, 120(1983) 
3) Itaya, K., S. Sugawara, K. Arai and S. Saito : J. Chem. Eng. Japan, 17, 514 (1984)

4) Kameyama, T., K. Fukuda, M. Fujishige, H. Yokokawa and M. Dokiya : Hydrogen Energy Prog., 2, 569 (1981)

5) Kameyama, T., M. Dokiya, M. Fujishige, H. Yokoyama and K. Fukuda: Int. J. Hydrogen Energy. 8, 5 (1983)

6) Itoh, N., Y. Shindo, K. Haraya and T. Hakuma : Proceeding of Int'l Congress on Membrane and Membrane Processes, Tokyo, Japan, June 8-12, pp. 654 (1987)
7) Asaeda, M. and L.D. Du : J. Chem. Eng. Japan, 19, 72(1986)

8) Asaeda, M., L.D. Du and M. Fuji : J. Chem. Eng. Japan, 19, 84(1986)

9) Asaeda, M., L.D. Du and K. Ikeda: J. Chem. Eng. Japan, 19, 238 (1986)

10) Lee, K. H. and S. T, Hwang : J. Colloid Interface Sci., 110, 544 (1986)

11) Niwa, M., H. Ohya, Y. Tanaka, N. Yoshikawa, K. Matsumoto and Y. Negishi : J. Membrane Sci., 39, 301 (1988)

（受付 1989 年 12 月 4 日）

\section{$90 / 2$ 高分子可能性講座}

主題 $=$ 高機能, 高性能新素材のフロンティア

一一ーパー微粒子/スーパーフィルム/スーパー繊維の開発動向—

最近，スーパー微粒子，スーパーフィルム，スーパー繊維がめざましい発展をとげ，産業界， 学会で注目されている.スーパーとは, 従来の機能, 性能をはるかに越えた高機能, 高性能化を めざす意味であり，新しいスーパー工業材料ともよぶべき技術のフロンティア領域について展望 する.

微粒子, フィルム, 繊維はそれぞれ別の分野のようにも見えるが実はそうではない. 超微粒子 クラスターから超薄膜が得られ, ノズルの違いからフィルムや繊維に分かれることからも十分理 解されよう。

本講座では, 最近, とくに開発の著しいスーパー微粒子, スーパーフィルム, スーパー繊維に 総合的なスポットをあて, 特別企画として参加者との質疑応答によるパネル討論を加え, 開発動 向と将来を展望したい. 21 世紀に通用するスーパー機能材料を創造, 開発しようとする研究者 ・技術者の方々によって, 必ず役立つものと確信している.

奮って関係各位のご参加を期待しています.

主 催 : 高分子学会 行事委員会

協 賛: 日本化学会・繊維学会 - 日本材料学会 - 日本膜学会 - 化学工学会 - 粉体粉末冶金協会 (予定)

日 時: 1990 年 6 月 21 日(木) 22 日(金)

会＼cjkstart場：ダイヤモンドホール（東京都千代田区霞ヶ関 1-4-2ＴＥＬ 03-504-6881）

参加要領 : 1) 定員 100 名

2）参加費：会員（協賛学協会会員を含む）会社 24,720 円 大学・官公庁 9,270 円 学生 2,060 円 会員外 49,440 円

3）申込方法 : 氏名, 勤務先, 連絡先 (電話番号も), 所属会員番号, 送金月日を八ガ キに明記し，お申し込み下さい, 参加費は銀行振込（三井銀行新橋支店 普通口 座 0920867 (社) 高分子学会) でお支払い下さい.

連絡先 : ₹ 104 東京都中央区銀座 5 丁目 12 番 8 号(本州ビル)

（社）高分子学会 90/2 高分子可能性講座係 TEL 03-543-7857 